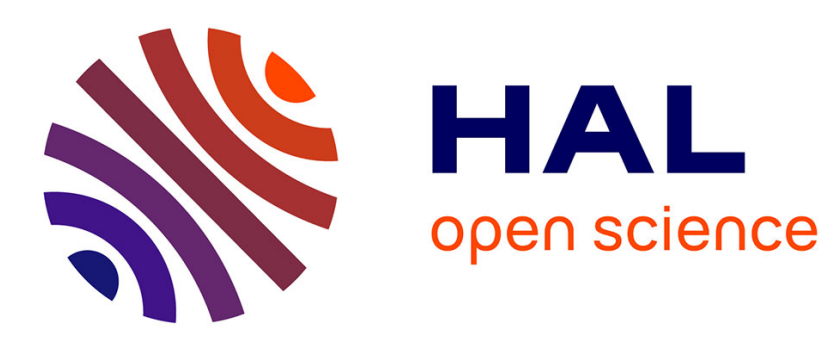

\title{
Functional structure and composition of Collembola and soil macrofauna communities depend on abiotic parameters in derelict soils
}

Quentin Vincent, Corinne Leyval, Thierry Beguiristain, Apolline Auclerc

\section{- To cite this version:}

Quentin Vincent, Corinne Leyval, Thierry Beguiristain, Apolline Auclerc. Functional structure and composition of Collembola and soil macrofauna communities depend on abiotic parameters in derelict soils. Applied Soil Ecology, 2018, 130, pp.259-270. 10.1016/j.apsoil.2018.07.002 . hal-01930921

\section{HAL Id: hal-01930921 \\ https://hal.science/hal-01930921}

Submitted on 8 Mar 2019

HAL is a multi-disciplinary open access archive for the deposit and dissemination of scientific research documents, whether they are published or not. The documents may come from teaching and research institutions in France or abroad, or from public or private research centers.
L'archive ouverte pluridisciplinaire HAL, est destinée au dépôt et à la diffusion de documents scientifiques de niveau recherche, publiés ou non, émanant des établissements d'enseignement et de recherche français ou étrangers, des laboratoires publics ou privés. 
5 Quentin VINCENT ${ }^{1,2}$, Corinne LEYVAL ${ }^{1}$, Thierry BEGUIRISTAIN ${ }^{1}$ and Apolline

6 AUCLERC ${ }^{2}$.

$7 \quad$ 1. Université de Lorraine, CNRS, LIEC, F-54000 Nancy, France macrofauna communities depend on abiotic parameters in

\author{
derelict soils
}

更

\author{
${ }^{2}$. Université de Lorraine, INRA, LSE, F-54000 Nancy, France.
}

\section{ABSTRACT}

In the last decades, anthropogenic disturbances have altered the ability of soils to provide diverse functions. Certain anthropogenic soils, with a low fertility level and often contaminated, ended up underused and derelict. Although derelict for humans, these soils may be refuges for biodiversity, but their biological functioning remains poorly understood. To this end, a trait-based approach of soil invertebrate communities might be an effective predictor of ecosystem state. The present work aims to highlight the in situ links between the abiotic characteristics of derelict soils and the taxonomic and functional structure and composition (through a trait-based approach) of macrofauna and Collembola communities inhabiting these soils. We studied 6 different derelict soils: two soils from coking plants, one soil from a settling pond, two constructed soils, and an inert waste storage soil. We measured fifteen abiotic soil parameters that inform on fertility and contamination. We took into account sixteen traits and ecological preferences to characterize the functional structure and composition of Collembola and macrofauna communities. Soil fertility (organic matter content, C:N ratio, P, Ca and 
$\mathrm{Mg}$ concentrations, cation-exchange capacity, and clay content) and moderate contamination $(\mathrm{Pb}, \mathrm{Cd}$, $\mathrm{Zn}$, and PAH concentrations) altered the taxonomic and functional composition of Collembola and macrofauna communities by selecting traits such as body length, pigmentation, vertical distribution, diet type, and habitat preference. Compost-amended constructed soil properties selected taxonomic and functional community composition of slightly disturbed soil. In contrast, metal-contaminated constructed soil harbored a higher proportion of Collembola displaying the traits and ecological preferences of instable ecosystems. The study of functional profiles of Collembola and macrofauna communities in the derelict soils evidenced that they support different communities with more or less wide functional potential. It underlines the interest of multiple biotic component studies to reach a better ecosystem description.

\section{HIGHLIGHTS}

Collembola and macrofauna communities from derelict soils were characterized.

Links between fauna community composition and soil characteristics were studied.

Fertility and contamination altered invertebrate community structure and composition.

Compost-amended constructed soil selected typical slightly disturbed soil species.

Collembola species traits in contaminated and constructed soil were typical of instable ecosystems.

\section{KEYWORDS}

Derelict soils, Functional diversity, Traits and ecological preferences, Soil invertebrates, Technosol

\section{INTRODUCTION}


Soils are complex ecosystems, described as multifunctional systems because many components interact inside them (Kibblewhite et al., 2008; Briones, 2014). Nevertheless, over the last decades growing evidence has emerged about the negative impact of anthropogenic disturbances on the ability of soils to provide functions (Levin et al., 2017) and occasionally to host biodiversity (Orgiazzi et al., 2016). In this context, the closing down of steel, shipbuilding or metal manufacturing industries because of economic issues and the closing down of mining sites in different European countries have resulted in land abandonment and altered ecosystem functioning (Wong and Bradshaw, 2002). Sometimes called greenfields, wastelands, uncultivated/vacant/abandoned lands, the soils of these derelict lands can be disturbed, i.e. characterized by a low fertility level (Dickinson, 2003) and/or sometimes by contamination (Morel et al., 2005). These specific abiotic parameters can alter soil functions likely to be important for agriculture and lead to surfaces being unmanaged and underused (Cundy et al., 2016). In Vincent et al. (2018), we showed that derelict soils could have low organic matter and nitrogen contents, a low cation exchange capacity, alkaline conditions with cations occasionally lacking or in excess, and moderate organic and inorganic contamination linked to their history. Biotic parameters (i.e. plant, fauna and microorganism density and richness) co-varied more with soil fertility proxies than with soil contamination parameters in moderately contaminated derelict soils. Once soils are underused and abandoned by humans, they may turn into refuges for biodiversity provided that abiotic parameters are not extreme for life (Baranova et al., 2014). Derelict soils have been reported to harbor a rich invertebrate biodiversity: insects (Bonthoux et al., 2014), beetles (Eyre et al., 2003), carabids (Small et al., 2006), earthworms and Collembola (Butt and Briones, 2017). However, the biological functioning of derelict soils remains poorly understood as compared to forest or agricultural lands.

In this vein, trait-based approaches focusing on the characteristics of individuals provide an interesting tool to assess soil functioning (Verberk et al., 2013). Pey et al. (2014) defined traits in soil invertebrate studies as "morphological, physiological, phenological or behavioral features measurable at the individual level, from the cell to the whole-organism level, without reference to the environment or any other level of organization". Traits could be considered as functional because they impact 
organism fitness directly and indirectly (Violle et al., 2007). Finally, functional traits can help to understand the effect of environmental stressors on soil communities (Auclerc et al., 2009; Vandewalle et al., 2010; Hedde et al., 2012; Salmon and Ponge, 2012). In recent years, traits have been recognized as effective predictors of exposure to disturbances (metal contamination in Hedde et al., 2012; restoration practices in Rosenfield and Müller, 2017), or of management strategies such as intensive agriculture, polyculture and monoculture (Wood et al., 2015; Sechi et al., 2017) to better understand the soil functional community structure and composition.

The functional community composition of the soil fauna is linked to soil abiotic parameters. For example, in urban soils, the proportion of Collembola with a sexual reproduction type was positively correlated with total $\mathrm{Cu}$ and $\mathrm{Ni}$ concentrations, and the proportion of pigmented Collembola was positively correlated with total $\mathrm{Cr}, \mathrm{Pb}$ and $\mathrm{Zn}$ concentrations (Santorufo et al., 2015). The proportion of Collembola living belowground (with the following trait attributes: small size, reduced or absent sensorial organs and furca, non-sexual reproduction type) in coal mine spoil tip soils was found associated to a coarser soil texture and higher nitrogen and organic matter concentrations (Vanhee et al., 2017). In parallel, the proportion of macroinvertebrates with a soft body decreased when metal contamination increased (Hedde et al. (2012), and the body size of ants was found driven by soil granulometry (Costa-Milanez et al. (2017). Moreover, other authors showed that soil age played a key role in the functional community composition by selecting certain traits such as moisture or light requirement in carabid communities (Aubin et al., 2013) or the feeding group for macrofauna communities (Frouz et al., 2013). To our knowledge, existing studies dealing with trait-based approaches in anthropogenic sites focussed on only one group of soil invertebrates (Collembola or carabids or macrofauna) and were carried out on highly contaminated and/or low fertile soils. Furthermore, there are too few studies considering the links between soil chemistry parameters and trait-based invertebrate community composition (e.g. Salmon and Ponge, 2012; Santorufo et al., 2014, Santorufo et al., 2015; Martins da Silva et al., 2016).

The present work aims to characterize which environmental factors shape macrofauna and Collembola invertebrate communities and their functional structure and composition in derelict soils characterized 
by moderate contamination and/or low fertility. We hypothesized that the soil characteristics related to past industrial activities and/or to the materials used for construction drove the composition of invertebrate communities by selecting certain traits and ecological preferences. We studied 6 different derelict soils: two soils from coking plants, one soil from a settling pond, two constructed soils, and an inert waste storage soil (Vincent et al., 2018). We took into account sixteen traits and ecological preferences to characterize the functional structure and composition of the soil invertebrate communities.

\section{MATERIALS AND METHODS}

\subsection{Derelict soils and fauna sampling methods}

We studied six soils from open industrial derelict sites located in north-eastern France in a historically industrial region, with many former coking plant sites and steel factories. The climate in this region is continental with annual mean temperature of $10.8^{\circ} \mathrm{C}$. For the sampling year (2015), monthly mean temperatures ranged between 1.8 and $22.1{ }^{\circ} \mathrm{C}$ and cumulated annual rainfall was around $500 \mathrm{~mm}$. Soil and fauna were sampled between the $8^{\text {th }}$ and $29^{\text {th }}$ of April 2015 (Vincent et al., 2018), during the period of highest invertebrate activity.

Soil named "CS" (for constructed soil) was a 1.13 ha experimental constructed soil set up on the site of a former coking plant (Séré et al., 2008). Soil named "WL" (for waste landfill) was from a 0.7 ha non-hazardous waste landfill. Soils named "CP1" and "CP2" (for coking plant site 1 and 2, respectively) were from former coking plant sites. These two soils differed in metal trace element concentrations. Soil named "SP" (for settling pond) was from a settling pond site filled with steel sludge. Lastly, soil named "CCS" (for constructed and contaminated soil), was an experimental 0.09ha constructed soil. See Table 1 for more details. 
We measured eleven abiotic variables that describe soil fertility: organic matter (OM) content, water holding capacity (WHC), clay content, exchangeable $\mathrm{Ca}, \mathrm{K}, \mathrm{Mg}$ and $\mathrm{Na}$ cation concentrations, Olsen phosphorus content, $\mathrm{pH}$, cation-exchange capacity (CEC), C:N ratio. We also measured four chemical variables to quantify the contaminant levels in the soils, i.e. $\mathrm{PAH}$ and available $\mathrm{Cd}, \mathrm{Zn}$ and $\mathrm{Pb}$ concentrations. We also took into account the time span since the last anthropogenic action on each site. The abiotic characteristics are summarized in Table 1 (for more details see Vincent et al. 2018)).

We took five soil samples from each derelict site (except for CCS where four samples were taken), along a 20-m transect with $5 \mathrm{~m}$ distance between each sample, in accordance with the Tropical Soil Biology and Fertility (TSBF) method (Anderson and Ingram 1993). We characterized communities in open areas (i.e. not forested areas) and adjusted our transect strategy to avoid potential edge effects for one given site. Collembola communities were sampled using soil cores and MacFadyen method, and macrofauna communities were sampled by soil blocks and hand-sorting method. Collembola were sampled on the 6 plots, on $10 \mathrm{~cm}$ depth, using two 5-cm deep corers (according to the ISO 23611-2 standard), fitted one above the other. The microarthropods were extracted using a high-temperature gradient extractor (MacFadyen, 1961) and identified to the species level. The soil macrofauna communities were studied on 5 sites by excavating $0.25 \times 0.25 \times 0.30 \mathrm{~m}$ soil blocks, according to the ISO 23611-5 standard. Macrofauna community from CCS was not studied because the destructive method would have caused high disturbances on the experimental plots. Macrofauna organisms were hand-sorted in laboratory, and kept in a 70\% (v/v) ethanol solution. They were all identified down to the family level, and further down to the species level for rove beetles, ground beetles and earthworms. Ants were removed from all analyses because these social insects are highly aggregated in space (Nahmani and Rossi 2003).

\subsection{Functional study (trait-based approach) of Collembola and macrofauna}

\section{communities}

We selected 7 traits for the trait-based approach of the Collembola study: body length (BLN), body shape (BSH), number of ocelli (OCE), presence of a post antennal organ (PAO), pigmentation (PIG), 
motion strategy (MS), reproduction type (REP), and 3 ecological preferences: vertical distribution (DIST), micro-habitat preference (MHABI), and habitat preference (HABI). As for the macrofauna, we selected 3 traits: body length (BLN), presence of an integument (INT), and mouth part type (MthT), and 3 ecological preferences: diet type (DIET), micro-habitat preference (MHABI), and habitat preference (HABI). These traits were chosen because they are commonly used to characterize the dispersal abilities of organisms in a given ecosystem, or to describe habitats and environmental stressors (Makkonen et al., 2011).

We gathered values (e.g. attributes) of the traits and ecological preferences of species from various sources (aggregated data, books, literature, etc.) but mainly from the BETSI (Biological and Ecological Traits of Soil Invertebrates - http://betsi.cesab.org) database. We used 8,200 Collembola data and 1,400 macrofauna data. The different traits/ecological preferences and attributes we assessed are listed in Table 2.

To analyze attribute data for a given taxon, we performed a fuzzy coding analysis. This method was developed by Chevene et al. (1994) and is widely used for trait approaches. Calculations were performed according to the method of Hedde et al. (2012). The information obtained from each source was coded by an affinity score for a given taxon and for a given trait attribute ranging from 0 to 4 (from no (0) to very high affinity (4) of the taxon to a trait attribute, respectively). Subsequently, the affinity scores obtained from all the sources were added up and transformed into a percentage to build the trait profile of each species/taxon. Finally, for each trait attribute, the mean affinity for the entire Collembola or macrofauna community, called Community Weighted Mean (CWM), was calculated according to Garnier et al. (2004). The CWM calculation was performed using equation 1,

\section{(Eq. 1) $\quad C W M=\sum_{i=1}^{n} P_{i} \times T_{i}$,}

where $P i$ is the relative abundance of species/taxon $i, n$ is the number of Collembola or macrofauna taxa, and $T_{i}$ is the relative trait/ecological preference attribute affinity of species/taxon $i$.

CWMs were calculated separately for Collembola and macrofauna communities, for each trait attribute in each sample, using the vegan package (Oksanen et al., 2017) in R software (version 3.1.3, 


\subsection{Taxonomic and functional diversity indices of Collembola and} macrofauna communities

We measured different ecological indices that describe taxonomic or functional community structure because they are commonly used to assess ecosystem stability and functioning (Tilman, 2001; Tilman et al., 2014; Bukvareva, 2017). For a taxonomic description of the communities sampled in each derelict soil, we estimated taxonomic richness (TRic) and taxonomic evenness (TEve) using the vegan package (Oksanen et al., 2017) in R software. TRic was the number of taxa composing the Collembola or macrofauna communities sampled in each derelict soil, and TEve was the partitioning of individuals among the different taxa across each community.

For a functional description of Collembola and macrofauna community structure, we calculated functional richness (FRic) and functional evenness (FEve) according to (Villéger et al., 2008), using trait values (Laliberté et al., 2014). FRic was the volume created by attribute values in a multidimensional trait space. FEve was the evenness with which attributes were distributed in the multidimensional functional space. These functional indices were calculated using R software and the FD package (Laliberté et al., 2014).

\subsection{Statistical and multivariate analyses}

To test the differences in functional community composition among soils, we independently performed univariate tests on CWMs for each attribute of a given trait. We also performed univariate tests on TRic, TEve, FRic and FEve to compare taxonomic and functional diversity levels among soils. As no dataset followed the conditions of parametric tests (we checked normality with Shapiro Wilk's test and homogeneity of variances with Bartlett's test), we performed Kruskal-Wallis (K-W) tests followed by the Dunn's test of multiple comparisons with Bonferroni adjustment to control the experimentwise error rates (Dinno, 2017). We used R Software for data processing, and performed all univariate tests with a $95 \%$ significance level. 
To highlight the relationships between the trait/ecological preferences and abiotic parameters of the derelict soils, we performed RLQ analyses (Dolédec et al., 1996). RLQ analysis is a generalization of co-inertia analysis (Dray et al., 2003) that couples multiple data sets and identifies co-relationships between them. RLQ analysis performs a double inertia analysis of two arrays (tables R and Q) with a link expressed by a contingency table (table L). RLQ analysis is a method to highlight how the environment filters certain species traits (Dray et al., 2014). We used it to provide simultaneous ordination, and to analyze the joint structure of three datasets: the abiotic parameter dataset of each sample (table R), the relative abundance of taxa in each sample (table L), and the attribute trait values for each taxon (table Q). We tested the significance of the relationship between taxon traits and abiotic parameters using a Monte Carlo test (999 permutations). We performed RLQ analysis for Collembola and macrofauna communities separately, using the ade4 package (Dray and Dufour, 2007) in R software. This approach is one of the most integrated methods to analyze trait-environment relationships (Dray and Dufour, 2007; Kleyer et al., 2012). We tested linear regressions with the lmtest package in $\mathrm{R}$, and correlations between abiotic and biotic parameters with the Pearson correlation coefficient (Hothorn et al., 2015).

\section{RESULTS}

\subsection{Collembola communities from all 6 derelict soils}

The density of Collembola ranged between 17,000 and 91,000 individuals per $\mathrm{m}^{2}$ on average, and their taxonomic richness between 3.4 and 7 per sample (Table 3). As regards the taxonomic approach, Collembola species richness was the highest in SP, CP2 and CCS, and significantly different from CS (K-W test; $\mathrm{P}=0.005)$. The evenness of Collembola species did not significantly differ among soils, with mean values ranging from 0.46 to 0.74 . As for the trait-based approach, Collembola functional richness (between 0.02 and 0.16 ) was the highest in $\mathrm{CP} 1, \mathrm{SP}$ and $\mathrm{CP} 2$, and significantly different from WL and CCS (K-W test; $\mathrm{P}<0.001)$. No difference in the functional evenness of Collembola communities was found among soils, with mean values ranging between 0.62 and 0.71 . 
Figure 1 shows the CWM of each attribute measured for each of the ten traits/ecological preferences of the Collembola communities sampled in each of the six derelict soils. For habitat preference, the Collembola collected through the study are forest and grassland taxa (81\% of the community on average for the 6 soils) and preferred soil as a micro-habitat (64\% of the community on average for the 6 soils).

CS harbored a higher proportion of Collembola that have a furca and inhabiting decaying woods ( $c a$. 24\%) than in CP1, SP and CP2. CCS was characterized by a higher proportion of Collembola with the biggest size (2-3 mm; ca. 49\%) compared to WL, SP and CP2. The percentage of Collembola with a PAO was higher in CCS ( $c a .88 \%)$ than in WL. Collembola in soil CCS have a higher number of ocelli $(5,6,7$ or 8 pairs; $c a .100 \%)$, they are more pigmented (ca. $88 \%)$ compared to soils CP1 and SP, and have a sexual reproduction type (ca.88\%), with an epiedaphic ecological preference ( $c a .93 \%$, a significant higher value compared to CS, CP1 and SP). CCS harbored the lowest proportion of Collembola inhabiting forests and grasslands (62\% of the community) but the highest proportion of Collembola inhabiting agricultural (22\% of the CCS community) and wetland habitats (14\% of the community).

According to Figure 2A, the first two RLQ analysis axes accounted for $88 \%$ of total Collembola community variance (69 and 19\%, respectively). The Monte-Carlo permutation test evidenced a global link between physico-chemical soil variables and the traits/ecological preferences of Collembola ( $\mathrm{P}$ value: 0.052 ). The projection of the centroid calculated for each soil separated them into 4 groups: CCS; WL-CP1-CP2; CS; SP. Species composition is given in Figure 2B. Isotomurus fucicolus, Isotomurus antennalis, Desoria violacea, Proisotoma minuta and Entomobrya lanuginosa were in the highest density in CCS as compared to the other soils. I.fucicolus, I.antennalis and P.minuta were only sampled in this soil. Likewise, CP2 hosted Smithurinus schoetti, Sphaeridia pumilis and Sminthurinus elegans in a higher abundance than the other soils. S.schoetti was only sampled in CP2. Metaphorura affinis, Cyphoderus albinus and Paratullbergia callipygos had the highest density in SP. The other soils (CS, WL, CP1, and CCS) did not host exclusive Collembola species (i.e. sampled in only one of the six soils). 
Figure $2 \mathrm{C}$ shows that the highest proportion of Collembola inhabiting mineral micro-habitats was

252

253

254

255

256

257 associated with the highest $\mathrm{C}: \mathrm{N}$ ratio, $\mathrm{pH}$ and $\mathrm{Ca}$ concentration and a small quantity of clay, which were the abiotic characteristics of SP. The higher proportions of forest- and grassland-inhabiting Collembola were associated with high $\mathrm{OM}$ contents and low trace elements $(\mathrm{Cd}, \mathrm{Zn}, \mathrm{Pb})$ concentrations in soils. These trait-abiotic parameter relationships were characteristic of CS, and to a lesser extent of $\mathrm{WL}, \mathrm{CP} 1$ and $\mathrm{CP} 2$. CCS had the highest $\mathrm{Cd}, \mathrm{Zn}$ and $\mathrm{Pb}$ concentrations and the lowest OM content. It hosted the highest proportion of Collembola with a high number of pairs of ocelli (i.e. $5,6,7$ or 8 ), and the highest proportion of Collembola inhabiting wetland habitats. The highest proportion of Collembola inhabiting in root and soil micro-habitats was associated with the highest soil CEC values in CS and to a lesser extent in WL, CP1 and CP2. Finally, the highest proportion of Collembola with a low number of ocelli (i.e. 1, 2, 3 or 4) was associated with the highest soil CEC and PAH concentrations, such as measured in CS. The other traits/ecological preferences were not clearly linked to measured physico-chemical parameters. Moreover, the time span since the last anthropogenic action on each site (i.e. "age") did not seem to influence trait selection across the sites.

\subsection{Macrofauna communities in 5 derelict soils}

The average macrofauna density ranged between 118 and 668 individuals per $\mathrm{m}^{2}$, and the average taxonomic richness of the macrofauna community ranged between 3.0 and 11.6 per sample (Table 3 ). Taxon richness (between 6.0 and 16.2) was significantly higher in CS and WL than in SP and CP2 (K$\mathrm{W}$ test; $\mathrm{P}=0.001$ ). No significant difference in the evenness of macrofauna taxa was measured among soils, with mean values ranging from 0.53 to 0.71 . Functional richness (between 0.06 and 0.14 ) was significantly higher in $\mathrm{CS}$ than in $\mathrm{SP}, \mathrm{CP} 1$ and $\mathrm{CP} 2$ (K-W test; $\mathrm{P}=0.041)$. As for Collembola community results, no difference in functional evenness was measured among soils, with mean values ranging from 0.74 to 0.78 .

Figure 3 shows the CWM of the six traits/ecological preferences of the macrofauna communities sampled in the five soils. For habitat preference, the macro invertebrates of the 5 soils are forest and 
grassland habitat taxa (around $50 \%$ of the community in the 5 soils, without significant difference among sites).

CS was characterized by a significantly higher proportion of invertebrates without a specific mouthpart (mainly earthworms; $c a$. 40\%) compared to other soils; CS harboured also a higher proportion of geophageous trophic group (ca. 24\%) compared to WL, SP and CP2 and a higher proportion of invertebrates inhabiting a mineral micro-habitat ( $c a .58 \%)$. SP was characterized by a higher proportion of small invertebrates $(2.5-5$ and $5-10 \mathrm{~mm} ; c a .40 \%)$ than in the other soils, and a higher proportion of invertebrates with a chewing mouthpart type (ca. 92\%). SP was also characterized by higher proportion of zoophagous trophic groups ( $\mathrm{ca} .58 \%)$ and of wetland habitat $\operatorname{taxa}(c a .37 \%)$.

The first two RLQ analysis axes accounted for $87 \%$ of total macrofauna community variance (71 and 16\%, respectively) (Figure 4A). The Monte-Carlo permutation test indicated a highly significant $(\mathrm{P}=0.01)$ link between physico-chemical variables and traits/ecological preferences of soil macroinvertebrates. The projection of the centroid calculated for each soil delineated 3 groups: CS; WLCP2; CP1-SP. Taxon composition is presented in Figure 4B. Athous click-beetle, Dermaptera, Allolobophora chlorotica, Allolobophora oculata and Aporrectodea longa earthworms had a higher density in CS than in the other soils. The Miridae group were in a higher density in WL and CP2 than in the other soils. Limacidae, the spider family Linyphiidae, the centipede family Geophilidae and the millipede order Julida (with especially the species Ommatoiulus sabulosus) had a higher density in CP2 than in the other soils. Finally, Steninae and Staphylinidae were in a higher density in SP than in the other soils.

Figure 4C shows that the highest proportions of macrofauna without a mouthpart, geophagous invertebrates and animals with a preference for agricultural habitats were associated with higher soil CEC and WHC, which were characteristic of CS. A weak but significant positive correlation was observed between earthworm density and soil $\mathrm{CEC}$ values $\left(\mathrm{R}^{2}=0.40\right.$; $\mathrm{T}$-test; $\left.\mathrm{P}<0.001\right)$ and between earthworm density and $\mathrm{OM}$ content $\left(\mathrm{R}^{2}=0.26\right.$; $\mathrm{T}$-test; $\left.\mathrm{P}=0.01\right)$. The highest proportion of invertebrates 
inhabiting mineral micro-habitats was associated with the highest soil PAH, phosphorous, and available $\mathrm{Cd}$ concentrations and the highest $\mathrm{OM}$ content. The highest proportion of invertebrates with a wetland habitat preference was associated with the highest soil $\mathrm{Mg}, \mathrm{Ca}$ and $\mathrm{Pb}$ concentrations, the highest C:N ratio and the lowest soil $\mathrm{K}$ concentration, characteristic of $\mathrm{CP} 1$ and SP. The highest proportion of individuals with a sclerotized integument was associated with the highest available soil $\mathrm{Zn}$ concentrations and lowest clay contents. The time span since the last anthropogenic action on each site (i.e. "age") did not seem to have any impact on functional community composition.

\section{DISCUSSION}

The use of functional traits of edaphic fauna highlighted differences in Collembola and macrofauna communities structures among the studied derelict soils. CS (a constructed compost amended soil) and WL (a non-hazardous waste landfill soil) had the highest taxonomic and functional macrofauna richness, but the lowest taxonomic and functional Collembola richness of the studied sites. These soils probably contained a high quantity of food resources and many potential different niches possibly linked to a high plant density, with no metal contamination. Focusing on earthworms, CS hosted the highest density of the studied sites. The presence of earthworms is currently considered as a good indicator of the absence of disturbance such as metal contamination and land-use intensification (Nahmani and Lavelle, 2002; Pérès et al., 2011; Cluzeau et al., 2012). We can suggest that competition for resources between meso- and macro-organisms can occur at one given time. For example, Eisenhauer (2010) showed negative impacts of endogeic earthworms due to competition for food resources with microarthropods such as Collembola. Earthworms can also affect the Collembola community by modifying, maintaining, creating or destroying habitats (Eisenhauer, 2010; Wright et al., 2012). At the opposite, CCS (an experimental constructed and contaminated soil) with the lowest fertility level and the highest metal concentration of the study, harbored the highest taxonomic 
diversity but a low functional diversity of Collembola. This might suggest functional redundancy of species within the community, defined as several species contributing in equivalent ways to an ecosystem function such that one species may substitute for another (Bruno et al., 2016). Species that are functionally redundant act as 'spare wheels' during a disturbance to maintain ecosystem functions (Cole et al., 2006). Functional redundancy of species in a given community might be interesting in disturbed habitats, and then a community composed of species with similar functional traits might be more resilient to a new disturbance (Gerisch, 2014; Hodecek et al., 2016).

Following the RLQ analyses, the differences in fertility levels and contaminant concentrations among the 6 anthropogenic derelict soils appeared to be associated with different composition of Collembola and macrofauna communities at the taxonomic and functional levels, with difference of response for both communities.

Firstly, the OM content was associated with the presence of Collembola Lepidocyrtus lanuginosus and Isotomiella minor, found at high densities in soils with high OM contents (Santorufo et al., 2014) and in coal mine spoil tip soils (Vanhee et al., 2017). These species are considered as forest-inhabiting species (Heiniger et al., 2015). They have been showed to prefer soils with dense vegetation (high plant biomass) and rich in OM (Gillet and Ponge, 2004; Fjellberg, 2007; Dunger and Schlitt, 2011). The OM content, which was the highest in CS owing to compost addition, appeared to positively influence the density of forest- and grassland-inhabiting Collembola in our study, but had no effect on the macrofauna. Collembola communities could be more driven by fine OM (only OM smaller that $2 \mathrm{~mm}$ was assessed in this study) than macrofauna because of the size of the food they eat. Secondly, the highest soil $\mathrm{C}: \mathrm{N}$ ratio was linked to the highest proportion of wetland-inhabiting macrofauna sampled in SP and CP1 (settling pond and coking plant soils, respectively). Wetlands harbor plant communities with a high C:N ratio that are decomposed slowly (Plum, 2005) and can in turn result in a high soil C:N ratio. Thirdly, the soil CEC value was linked to the proportion of invertebrates without a mouthpart, mainly represented by earthworms, in WL. The selection of earthworm populations (geophageous invertebrates without a mouthpart) by high soil CEC has already been observed in soils of oil palm plantations and agricultural areas (Sabrina et al., 2009; Hedde et al., 2012). The authors 
underlined that the effects of CEC on earthworm populations was similar to the effects of organic carbon. In our study, a weak correlation was observed between earthworm density and OM content or CEC values. The soil CEC value also seemed to be an important factor on Collembola species characterized by trait attributes linked to a high dependence on soil as a habitat (i.e. "soil-inhabiting", "inhabiting root micro-habitats" and "low number of ocelli"). Finally, $\mathrm{Ca}$ and $\mathrm{Mg}$ concentrations in the soils also appeared to alter the proportion of chewing mouth-part type macrofauna that we assumed to use herbaceous litter as food. An explanation of this abiotic-biotic link could be that the $\mathrm{Ca}$ concentrations in plants and consequently in litter originate from the soil. Thus, in the studied soils, litter calcium might have come from the materials used for constructing soils, and may have influenced the functional composition of soil invertebrates by selecting certain species with a specific mouth-part type.

Metal concentrations seemed also to influence the density of certain species and to alter the functional community composition of the soil biodiversity, especially for Collembola. In this vein, Proisotoma minuta was only found in the soil with the highest metal concentration (CCS). P.minuta has already been shown as an indicator of manure or slurry pollution and predominates in decaying sewage sludge (Dunger and Schlitt, 2011). It seems to be a generalist species adapted to different ecosystems likely to be altered. Euedaphic Collembola are considered as the most sensitive living forms to metal contamination according to several studies (Fountain and Hopkin, 2004; Parisi et al., 2005; Joimel, 2015). Epedaphic Collembola, are more resistant to pollutants than euedaphic Collembola because they have a higher movement ability and a lower direct contact with soil particles (Fountain and Hopkin, 2004). This result is consistent with our findings: the derelict soil with the highest metal concentrations (CCS) did not host euedaphic Collembola. In the present study, the metal concentration also appeared to positively drive the proportion of Collembola with a maximum number of ocelli, as observed previously for soil $\mathrm{Pb}$ concentrations (Joimel, 2015). The number of ocelli is an indicator of the dispersal ability of Collembola since species with a complete visual apparatus can disperse rapidly (Ponge et al., 2006; Salmon et al., 2014). Several authors underlined that Collembola with a high dispersal ability were present in disturbed environments (Auclerc et al., 2009; Salmon et al., 2014; 
Joimel, 2015). Thus, the metal concentrations of our soils, though low as compared to other studies on

382

383

384

385

386

387

388

389

390

391

392

393

394

395

396

397

398

399

400

401

402

403

404

405

406

407

anthropogenic soils, appeared to have selected Collembola with a high dispersal ability linked to specific morphological traits. In the same vein, the highest proportion of Collembola with sexual reproduction was observed in CCS, which contained the highest metal concentrations. A higher proportion of sexual reproduction species as compared to parthenogenetic Collembola species has been reported in copper-polluted environments (Niklasson et al., 2000). The reproduction type of Collembola is associated with survival or colonizing strategies (Salmon et al., 2014). Sexual reproduction favors polymorphism and is an advantage for colonizing disturbed ecosystems like polluted soils on a long term (Austruy et al., 2016). According to the trait-based approach, individuals with a long body, several ocelli, a PAO organ, a sexual reproduction type, an epiedaphic living form and a pigmented body mainly represented the Collembola community in soil F. All of these trait attributes are characteristic of organisms inhabiting in urban environments (Santorufo et al., 2014), and are linked to a good dispersal ability that allows adaptation to disturbed habitats. The age effect was not a major factor explaining the functional composition of communities according to the RLQ. Yet, we may expect links between the fact that CCS was the youngest plot and that it hosted a Collembola community rich in high dispersal capacity species, which are best adapted for site colonization.

Regarding macrofauna community, available soil $\mathrm{Pb}$ concentrations seemed to influence earthworm density: the highest earthworm density was found in soils with low metal contamination (CS and WL) as compared to other soils. This impact of $\mathrm{Pb}$ concentrations on earthworm communities has been shown by Lévêque et al. (2015), who observed a low earthworm density in soils near a Pb-recycling factory containing a high total $\mathrm{Pb}$ concentration $\left(2,010 \mathrm{mg} \cdot \mathrm{kg}^{-1}\right.$ of $\mathrm{Pb}$ on average, that is a higher concentration than in our soils). Pižl and Josens (1995) also observed a low earthworm density in soils with a moderate $\mathrm{Pb}$ concentration (89 ind. $\mathrm{m}^{-2}$ in a soil containing $108 \mathrm{mg} \cdot \mathrm{kg}^{-1}$ of total $\mathrm{Pb}$ ) as compared to a soil with a low $\mathrm{Pb}$ concentration $\left(490\right.$ ind. $\mathrm{m}^{-2}$ in a soil containing $25 \mathrm{mg} \cdot \mathrm{kg}^{-1}$ of total $\mathrm{Pb}$ ). In our study, we found 42 and 48 earthworms. $\mathrm{m}^{-2}$ on average in the soils with the highest total $\mathrm{Pb}$ concentrations (346 and $339 \mathrm{mg} . \mathrm{kg}^{-1}$ for CP1 and SP, respectively) and 112 and 45 earthworms. $\mathrm{m}^{-2}$ on 
average in the soils with the lowest total $\mathrm{Pb}$ concentrations (41 and $37 \mathrm{mg} \cdot \mathrm{kg}^{-1}$ for WL and CP2, respectively). Other authors have also shown that earthworms were sensitive to metal pollution (Nahmani and Lavelle, 2002; Nahmani et al., 2005). As Collembola, earthworms abundance and diversity are dependent of soil properties, that highlight their bioindicator potential (Ponge et al., 2003; Pérès et al., 2011; George et al., 2017). Furthermore, a higher available soil Zn concentration was associated with a higher density of sclerotized macrofauna individuals. We can hypothesize that organisms with sclerotized integuments are more protected against pollutants because sclerotized integuments provide defence against chemical attacks (Linz et al., 2016). By contrast, soft-body individuals may be directly exposed to pollution by direct skin contact. A negative correlation has already been observed between the proportion of soft-body individuals and metal soil concentrations (Hedde et al., 2012).

Finally, at a larger spatial scale, the surrounding landscape would have to be taken into account in order to better understand the variability of community composition across sites. Collembola and macrofauna communities can be both affected by surrounding environment and vegetation in derelict soils (Cortet et al., 2013; Baranova et al., 2014; Vanhee et al., 2017). Although no geostatistical analyses were performed in the present study, some hypotheses might be suggested on species traits selection. For instance, we found that communities were dominated by forest and grassland habitat taxa, which can be explained by the surrounding landscapes around the sites. CP1, SP and CP2 were surrounded by forests, while CS, WL and CCS were surrounded by grasslands. This could explain the significant higher proportion of euedaphic, blind and non-pigmented Collembola in CP1 and SP, that are characteristics traits of forest-inhabiting species (Salmon et al., 2014). Moreover, the proportion of macrofauna inhabiting wet habitats was higher in SP than in CS, WL and CP2, which could be explained by the proximity to a river ( $c a .70 \mathrm{~m}$ away). The proportion of Collembola inhabiting wetland habitats was higher in CCS. The inefficient irrigation system in this experimental constructed soil probably allowed for colonization by wet-habitat species. Moreover, these species may have come from a nearby pond located at $300 \mathrm{~m}$ distance and been brought by trucks and human activities during the soil construction process or wind or animals (Costa et al., 2013). 


\section{CONCLUSION}

The diversity indices of Collembola and macrofauna communities showed different results attributable to differences in living modes between the two soil invertebrate communities (e.g. feeding groups and niche scales). It shows that the derelict soils support different communities with more or less wide functional potential depending on their physico-chemical characteristics. Our study revealed that derelict soil characteristics have more consequences on taxonomical and functional profiles of Collembola communities than macrofauna. In this sense, we can assume that Collembola are more relevant bioindicators of derelict soil characteristics than macrofauna. For instance, the studied more fertile and less contaminated compost-amended constructed soil exhibited taxonomic and functional community structures and composition of slightly disturbed soil. In contrast, the metal-contaminated constructed soil harbored a higher proportion of Collembola with the traits and ecological preferences of both unstable and scarcely vegetated ecosystems. Our study underlines the interest of trait-based approach and multi traits studies to assess the diversity of derelict soils and to reach a better understanding of soil ecosystem. However, in-depth analysis of direct relations between Collembola and macrofauna in these soils was limited due to different traits and attributes between both fauna groups in existing databases.

Since we studied invertebrate communities at one given season, it might be interesting to characterize the community response patterns at different seasons. We previously measured the potential mineralization activity of these derelict soils (Vincent et al., 2018), but in situ measurement of soil functions, such as organic matter decomposition - by litter bag method - or soil respiration, might add complementary information to link functional traits of the fauna with the derelict soil functioning. 
This work was carried out within the GISFI (Groupement d'interêt scientifique sur les friches

462

463

464

465

466

467 industrielles, www.gisfi.fr), within the framework of the LORVER project (www.lorver.org). It was supported by the French Lorraine Region and the European Regional Development Fund (ERDF). The authors wish to thank Mickaël Hedde and Jodie Thénard for identifying ground beetles and a few other coleoptera, and BETSI project colleagues for providing access to their database. We also thank Sandrine Salmon and Johanne Nahmani for coding the traits of numerous Collembola species, and Sophie Joimel for providing the Collembola trait database. We also thank the technical staff of the GISFI, LIEC and LSE for the sampling campaign, particularly Alain Rakoto.

\section{REFERENCES}

Anderson, J.M., Ingram, J.S.I., 1993. Tropical Soil Biology and Fertility-A handbook of methods. Soil Sci. 157, 265.

Aubin, I., Venier, L., Pearce, J., Moretti, M., 2013. Can a functional multi-taxa approach improve our assessment of forest management impact on biodiversity? Biodivers. Conserv. 22, 2957-2975.

Auclerc, A., Ponge, J.-F., Barot, S., Dubs, F., 2009. Experimental assessment of habitat preference and dispersal ability of soil springtails. Soil Biol. Biochem. 41, 1596-1604.

Austruy, A., Laplanche, C., Mombo, S., Dumat, C., Deola, F., Gers, C., 2016. Ecological changes in historically polluted soils: Metal(loid) bioaccumulation in microarthropods and their impact on community structure. Geoderma 271, 181-190.

Baranova, B., Manko, P., Jaszay, T., 2014. Waste dumps as local biodiversity hotspots for soil macrofauna and ground beetles (Coleoptera: Carabidae) in the agricultural landscape. Ecol. Eng. 81, 1-13.

Bonthoux, S., Brun, M., Di Pietro, F., Greulich, S., Bouché-Pillon, S., 2014. How can wastelands promote biodiversity in cities? A review. Landsc. Urban Plan. 132, 79-88.

Briones, M.J.I., 2014. Soil fauna and soil functions: a jigsaw puzzle. Front. Environ. Sci. 2, 1-22. 
Bruno, D., Gutiérrez-Cénovas, C., Velasco, J., Sànchez-Fernàndez, D., 2016. Functional redundancy as a tool for bioassessment: A test using riparian vegetation. Sci. Total Environ. 566-567, 12681276.

Bukvareva, E., 2017. The optimal biodiversity - A new dimension of landscape assessment. Ecol. Indic. nd.

Butt, K.R., Briones, M.J.I., 2017. Earthworms and mesofauna from an isolated, alkaline chemical waste site in Northwest England. Eur. J. Soil Biol. 78, 43-49.

Chevene, F., Doleadec, S., Chessel, D., 1994. A fuzzy coding approach for the analysis of long-term ecological data. Freshw. Biol. 31, 295-309.

Cluzeau, D., Guernion, M., Chaussod, R., Martin-Laurent, F., Villenave, C., Cortet, J., Ruiz-Camacho, N., Pernin, C., Mateille, T., Philippot, L., Bellido, A., Rougé, L., Arrouays, D., Bispo, A., Pérès, G., 2012. Integration of biodiversity in soil quality monitoring: Baselines for microbial and soil fauna parameters for different land-use types. Eur. J. Soil Biol. 49, 63-72.

Cole, L., Bradford, M.A., Shaw, P.J.A., Bardgett, R.D., 2006. The abundance, richness and functional role of soil meso- and macrofauna in temperate grassland-A case study. Appl. Soil Ecol. 33, $186-198$.

Cortet, J., Béguiristain, T., Charissou, A.-M., Chenot, E.-D., Corbel, S., Cluzeau, D., Hafeez, F., Hedde, M., Leyval, C., Martin-Laurent, F., Masfaraud, J.-F., Nahmani, J., Piron, D., Schwartz, C., Séré, G., Villenave, C., Watteau, F., 2013. Early colonisation of a constructed Technosol by soil organisms after industrial site reclamation, in: Soils of Urban, Industrial, Traffic, Mining and Military Areas. SUITMA 7. Torun, 16-20 September 2013. International Union of Soil Sciences (IUSS), pp. 119-120.

Costa-Milanez, C.B. da, Majer, J.D., Castro, P. de T.A., Ribeiro, S.P., 2017. Influence of soil granulometry on average body size in soil ant assemblages: implications for bioindication. Perspect. Ecol. Conserv. 15, 102-108.

Costa, D., Timmermans, M.J.T.N., Sousa, J.P., Ribeiro, R., Roelofs, D., Van Straalen, N.M., 2013. Genetic structure of soil invertebrate populations: Collembolans, earthworms and isopods. Appl. Soil Ecol. 68, 61-66. 
Cundy, A.B., Bardos, R.P., Puschenreiter, M., Mench, M., Bert, V., Friesl-Hanl, W., Müller, I., Li, X.N., Weyens, N., Witters, N., Vangronsveld, J., 2016. Brownfields to green fields: Realising wider benefits from practical contaminant phytomanagement strategies. J. Environ. Manage. 186, $67-77$.

Development Core Team, R., 2015. A language and environment for statistical computing. Austria, Vienna : the R foundation for statistical computing.

Dickinson, N., 2003. Soil degradation and nutrients, in: The Restoration and Management of Derelict Land: Modern Approaches. World Scientific, pp. 50-65.

Dolédec, S., Chessel, D., ter Braak, C.J.F., Champely, S., 1996. Matching species traits to environmental variables: a new three-table ordination method. Environ. Ecol. Stat. 3, 143-166.

Dray, S., Chessel, D., Thioulouse, J., 2003. Co- inertia analysis and the linking of ecological data tables. Ecology 84, 3078-3089.

Dray, S., Choler, P., Dolédec, S., Peres-Neto, P.R., Thuiller, W., Pavoine, S., Ter Braak, C.J.F., 2014. Combining the fourth-corner and the RLQ methods for assessing trait responses to environmental variation. Ecology 95, 14-21.

Dray, S., Dufour, A.B., 2007. The ade4 Package: Implementing the duality diagram for ecologists. J. Stat. Softw. 22, 1-20.

Dunger, W., Schlitt, B., 2011. Synopses on Palaearctic Collembola - Tullbergiidae. Senckenberg, Museum of Natural History.

Eisenhauer, N., 2010. The action of an animal ecosystem engineer: Identification of the main mechanisms of earthworm impacts on soil microarthropods. Pedobiologia (Jena). 53, 343-352.

Eyre, M.D., Luff, M.L., Woodward, J.C., 2003. Beetles (Coleoptera) on brownfield sites in England: An important conservation resource? J. Insect Conserv. 7, 223-231.

Fjellberg, A., 2007. Checklist of Nordic Collembola With notes on habitat preferences and presence/absence in individual countries. www.collembola.org.

Fountain, M.T., Hopkin, S.P., 2004. A comparative study of the effects of metal contamination on Collembola in the field and in the laboratory. Ecotoxicology 13, 573-587.

Frouz, J., Jílková, V., Cajthaml, T., Pižl, V., Tajovský, K., Háněl, L., Burešová, A., Šimáčková, H., 

mining sites along a climatic gradient in the USA: Simple communities in shortgrass prairie recover faster than complex communities in tallgrass prairie and forest. Soil Biol. Biochem. 67, $212-225$.

Garnier, E., Cortez, J., Billès, G., Navas, M., Roumet, C., 2004. Plant functional markers capture ecosystem properties during secondary succession. Ecology 85, 2630-2637.

Gerisch, M., 2014. Non-random patterns of functional redundancy revealed in ground beetle communities facing an extreme flood event. Funct. Ecol. 28, 1504-1512.

Gillet, S., Ponge, J.F., 2004. Are acid-tolerant Collembola able to colonise metal-polluted soil? Appl. Soil Ecol. 26, 219-231.

Hedde, Van Oort, F., Lamy, I., 2012. Functional traits of soil invertebrates as indicators for exposure to soil disturbance. Environ. Pollut. 164, 59-65.

Heiniger, C., Barot, S., Ponge, J.F., Salmon, S., Meriguet, J., Carmignac, D., Suillerot, M., Dubs, F., 2015. Collembolan preferences for soil and microclimate in forest and pasture communities. Soil Biol. Biochem. 86, 181-192.

557

Hodecek, J., Kuras, T., Sipos, J., Dolny, A., 2016. Role of reclamation in the formation of functional structure of beetle communities: A different approach to restoration. Ecol. Eng. 94, 537-544.

Hothorn, T., Zeileis, A., Farebrother, R.W., Cummins, C., Millo, G., Mitchell, D., 2015. lmtest: Testing linear regression models. R Packag. version 0.9-34.

ISO 23611-2, 2006. Soil quality -- Sampling of soil invertebrates -- Part 2: Sampling and extraction of micro-arthropods (Collembola and Acarina).

ISO 23611-5, 2011. Soil quality -- Sampling of soil invertebrates -- Part 5: Sampling and extraction of soil macro-invertebrates.

Joimel, S., 2015. Biodiversité et caractéristiques physico-chimiques des sols de jardins associatifs urbains français. Doctoral dissertation, University of Lorraine.

Kibblewhite, M., Ritz, K., Swift, M., 2008. Soil health in agricultural systems. Philos. Trans. R. Soc. Lond. B. Biol. Sci. 363, 685-701.

Kleyer, M., Dray, S., Bello, F., Lepš, J., Pakeman, R.J., Strauss, B., Thuiller, W., Lavorel, S., 2012. 
Assessing species and community functional responses to environmental gradients: Which multivariate methods? J. Veg. Sci. 23, 805-821.

572

573

574

575

576

577

578

579

580

581

582

583

584

585

586

587

588

589

590

591

592

593

594

595

Laliberté, E., Legendre, P., Shipley, B., Laliberté, M., 2014. FD: measuring functional diversity from multiple traits, and other tools for functional ecology. R Packag. version 1.0-12. 91, 299-305.

Lévêque, T., Capowiez, Y., Schreck, E., Mombo, S., Mazzia, C., Foucault, Y., Dumat, C., 2015. Effects of historic metal(loid) pollution on earthworm communities. Sci. Total Environ. 511, $738-746$.

Levin, M., Kim, K., Morel, J., Burghardt, W., Charzyński, P., Shaw, R., 2017. Soils within Cities. Global approaches to their sustainable management. Soil Use and Management, 33(4), 673-673. Linz, D.M., Hu, A.W., Sitvarin, M.I., Tomoyasu, Y., 2016. Functional value of elytra under various stresses in the red flour beetle, Tribolium castaneum. Sci. Rep. 6, 34813.

Macfadyen, A., 1961. Improved funnel-type extractors for soil arthropods. J. Anim. Ecol. 30, 171184.

Makkonen, M., Berg, M.P., van Hal, J.R., Callaghan, T. V., Press, M.C., Aerts, R., 2011. Traits explain the responses of a sub-arctic Collembola community to climate manipulation. Soil Biol. Biochem. 43, 377-384.

Martins da Silva, P., Carvalho, F., Dirilgen, T., Stone, D., Creamer, R., Bolger, T., Sousa, J.P., 2016. Traits of collembolan life-form indicate land use types and soil properties across an European transect. Appl. Soil Ecol. 97, 69-77.

Morel, J.L., Schwartz, C., Florentin, L., de Kimpe, C., 2005. Urban soils - Ed: Hillel, Daniel, in: Encyclopedia of Soils in the Environment. Elsevier, Oxford, pp. 202-208.

Nahmani, J., Capowiez, Y., Lavelle, P., 2005. Effects of metal pollution on soil macroinvertebrate burrow systems. Biol. Fertil. Soils 42, 31-39.

Nahmani, J., Lavelle, P., 2002. Effects of heavy metal pollution on soil macrofauna in a grassland of Northern France. Eur. J. Soil Biol. 38, 297-300.

Nahmani, J., Rossi, J.P., 2003. Soil macroinvertebrates as indicators of pollution by heavy metals. C. R. Biol. 326, 295-303.

Niklasson, M., Petersen, H., Parker, E.D., 2000. Environmental stress and reproductive mode in 
Oksanen, J., Blanchet, F.G., Kindt, R., Legendre, P., Minchin, P.R., Hara, R.B.O., Simpson, G.L.,

600

601

602

603

604

605

606

607

608

609

610

611

612

613

614

615

616

617

618

619

620

621

622

623

624

625

Solymos, P., Stevens, M.H.H., 2017. Package ‘vegan’ - Community Ecology Package.

Orgiazzi, A., Bardgett, R.D., Barrios, E., Behan-Pelletier, V., Briones, M.J.I., Chotte, J.-L., De Deyn, G.B., Eggleton, P., Fierer, N., Fraser, T., Hedlund, K., Jeffery, S., Johnson, N.C., Jones, A., Kandeler, E., Kaneko, N., Lavelle, P., Lemanceau, P., M, D.H., 2016. Global soil biodiversity atlas, Global soil biodiversity atlas. European Commission.

Parisi, V., Menta, C., Gardi, C., Jacomini, C., Mozzanica, E., 2005. Microarthropod communities as a tool to assess soil quality and biodiversity: A new approach in Italy. Agric. Ecosyst. Environ. $105,323-333$.

Pérès, G., Vandenbulcke, F., Guernion, M., Hedde, M., Beguiristain, T., Douay, F., Houot, S., Piron, D., Richard, A., Bispo, A., Grand, C., Galsomies, L., Cluzeau, D., 2011. Earthworm indicators as tools for soil monitoring, characterization and risk assessment: An example from the national Bioindicator programme. Pedobiologia - Int. J. Soil Biol. 54, S77-S87.

Pey, B., Nahmani, J., Auclerc, A., Capowiez, Y., Cluzeau, D., Cortet, J., Decaens, T., Deharveng, L., Dubs, F., Joimel, S., others, 2014. Current use of and future needs for soil invertebrate functional traits in community ecology. Basic Appl. Ecol. 15, 194-206.

Pižl, V., Josens, G., 1995. Earthworm communities along a gradient of urbanization. Environ. Pollut. $90,7-14$.

Plum, N., 2005. Terrestrial invertebrates in flooded grassland: A literature review. Wetlands 25, 721737.

Ponge, J., Dubs, F., Gillet, S., Sousa, J., Lavelle, P., 2006. Decreased biodiversity in soil springtail communities: the importance of dispersal and land-use history in heterogeneous landscapes. Soil Biol. Biochem. 38, 1158-1161.

Ponge, J.F., Gillet, S., Dubs, F., Fedoroff, E., Haese, L., Sousa, J.P., Lavelle, P., 2003. Collembolan communities as bioindicators of land use intensification. Soil Biol. Biochem. 35, 813-826.

Rosenfield, M.F., Müller, S.C., 2017. Predicting restored communities based on reference ecosystems using a trait-based approach. For. Ecol. Manage. 391, 176-183. 
Sabrina, D.T., Hanafi, M.M., Azwady Nor, A.A., Mahmud, T.M.M., 2009. Earthworm populations and cast properties in the soils of oil palm plantations. Malaysian J. Soil Sci. 13, $29-42$.

Salmon, S., Ponge, J.F., 2012. Species traits and habitats in springtail communities : A regional scale study. Pedobiologia (Jena). 55, 295-301.

Salmon, S., Ponge, J.F., Gachet, S., Deharveng, L., Lefebvre, N., Delabrosse, F., 2014. Linking species, traits and habitat characteristics of Collembola at European scale. Soil Biol. Biochem. $75,73-85$.

Santorufo, L., Cortet, J., Arena, C., Goudon, R., Rakoto, A., Morel, J.L., Maisto, G., 2014. An assessment of the influence of the urban environment on collembolan communities in soils using taxonomy- and trait-based approaches. Appl. Soil Ecol. 78, 48-56.

Santorufo, L., Cortet, J., Nahmani, J., Pernin, C., Salmon, S., Pernot, A., Morel, J.L., Maisto, G., 2015. Responses of functional and taxonomic collembolan community structure to site management in Mediterranean urban and surrounding areas. Eur. J. Soil Biol. 70, 46-57.

Sechi, V., De Goede, R.G.M., Rutgers, M., Brussaard, L., Mulder, C., 2017. A community trait-based approach to ecosystem functioning in soil. Agric. Ecosyst. Environ. 239, 265-273.

Séré, G., Schwartz, C., Ouvrard, S., Sauvage, C., Renat, J.C., Morel, J.L., 2008. Soil construction: A step for ecological reclamation of derelict lands. J. Soils Sediments 8, 130-136.

Small, E., Sadler, J.P., Telfer, M., 2006. Do landscape factors affect brownfield carabid assemblages? Sci. Total Environ. 360, 205-222.

Tilman, D., 2001. Functional diversity, in: Encyclopedia of Biodiversity. Academic Press, pp. 109121.

Tilman, D., Isbell, F., Cowles, J.M., 2014. Biodiversity and ecosystem functioning. Nature's Serv. Soc. Depend. Nat. Ecosyst. 93, 112.

Vandewalle, M., De Bello, F., Berg, M.P., Bolger, T., Dolédec, S., Dubs, F., Feld, C.K., Harrington, R., Harrison, P.A., Lavorel, S., 2010. Functional traits as indicators of biodiversity response to land use changes across ecosystems and organisms. Biodivers. Conserv. 19, 2921-2947.

Vanhee, B., Salmon, S., Devigne, C., Leprêtre, A., Deharveng, L., Ponge, J.-F., 2017. The 'terril' effect: Coal mine spoil tips select for collembolan functional traits in post-mining landscapes of 
northern France. Appl. Soil Ecol. 121, 90-101.

Verberk, W.C.E.P., van Noordwijk, C.G.E., Hildrew, A.G., 2013. Delivering on a promise: integrating species traits to transform descriptive community ecology into a predictive science. Freshw. Sci. $32,531-547$.

Villéger, S., Mason, N.W.H., Mouillot, D., 2008. New multidimensional functional diversity indices for a multifaceted framework in functional ecology. Ecology 89, 2290-2301.

Vincent, Q., Auclerc, A., Beguiristain, T., Leyval, C., 2018. Assessment of derelict soil quality: Abiotic , biotic and functional approaches. Sci. Total Environ. 613-614, 990-1002.

Violle, C., Navas, M.L., Vile, D., Kazakou, E., Fortunel, C., Hummel, I., Garnier, E., 2007. Let the concept of trait be functional! Oikos 116, 882-892.

Wong, M., Bradshaw, A., 2002. The restoration and management of derelict land: modern approaches. World Scientific.

Wood, S.A., Karp, D.S., DeClerck, F., Kremen, C., Naeem, S., Palm, C.A., 2015. Functional traits in agriculture: Agrobiodiversity and ecosystem services. Trends Ecol. Evol. 30, 531-539.

Wright, J.P., Gurney, W.S.C., Jones, C.G., 2012. Patch dynamics modified by ecosystem engineers. Oikos 105, 336-348. 
1 Table 1: Abiotic parameters of the six derelict soils. Means \pm SD $(n=5$, except for soil $F$ where $n=4)$.

2 Soil classification according WRB (2014); localization in the Lambert 93 projection in m; age is the

3 time lapse from the last anthropogenic action (years); clay and WHC in \%; $\mathrm{CEC}$ in $\mathrm{cmol}^{+} \cdot \mathrm{kg}^{-1}$ dry soil;

4 soil $\mathrm{pH}$ in water; Olsen Phosphorous in mg. $\mathrm{kg}^{-1}$ dry soil; $\mathrm{OM}$ in \%; Exchangeable $\mathrm{Ca}, \mathrm{K}, \mathrm{Mg}, \mathrm{Na}$ in

5 mg.kg ${ }^{-1}$ dry soil, Available and total $\mathrm{Cd}, \mathrm{Pb}, \mathrm{Zn}$ in $\mathrm{mg} \cdot \mathrm{kg}^{-1}$ dry soil; and $\mathrm{PAH}$ (Polycyclic Aromatic

6 Hydrocarbons) concentrations in $\mathrm{mg} \mathrm{kg}^{-1}$ dry soil. For more details, see Vincent et al. (2018).

\begin{tabular}{|c|c|c|c|c|c|c|}
\hline Soil abbreviation & CS & WL & CP1 & SP & CP2 & CCS \\
\hline $\begin{array}{l}\text { Soil name correspondence } \\
\text { with Vincent et al., } 2018\end{array}$ & $\mathbf{A}$ & B & $\mathbf{C}$ & D & $\mathbf{E}$ & $\mathbf{F}$ \\
\hline Site type and name & $\begin{array}{c}\text { Experimental } \\
\text { constructed } \\
\text { soil } \\
\text { (Biotechnosol) }\end{array}$ & $\begin{array}{c}\text { Non- } \\
\text { hazardous waste } \\
\text { landfill } \\
\text { (Retonfey) }\end{array}$ & $\begin{array}{l}\text { Coking plant } \\
\text { site } \\
\text { (Homécourt) }\end{array}$ & $\begin{array}{l}\text { Settling pond } \\
\text { site } \\
\text { (Moyeuvre- } \\
\text { Petite) }\end{array}$ & $\begin{array}{l}\text { Coking plant } \\
\text { site } \\
\text { (Micheville) }\end{array}$ & $\begin{array}{c}\text { Experimental } \\
\text { constructed and } \\
\text { contaminated } \\
\text { soil } \\
\text { (Jeandelaincourt) }\end{array}$ \\
\hline Soil classification & $\begin{array}{l}\text { Spolic Garbic } \\
\text { Technosol }\end{array}$ & $\begin{array}{l}\text { Skeletic } \\
\text { Technosol }\end{array}$ & $\begin{array}{c}\text { Spolic } \\
\text { Technosol }\end{array}$ & $\begin{array}{c}\text { Spolic } \\
\text { Technosol }\end{array}$ & $\begin{array}{c}\text { Spolic } \\
\text { Technosol }\end{array}$ & $\begin{array}{l}\text { Spolic } \\
\text { Technosol }\end{array}$ \\
\hline Composition & $\begin{array}{l}\text { paper mill } \\
\text { waste, thermal } \\
\text { desorption- } \\
\text { treated PAH- } \\
\text { contaminated } \\
\text { soil, and green- } \\
\text { waste compost }\end{array}$ & $\begin{array}{l}\text { ground } \\
\text { construction and } \\
\text { demolition } \\
\text { wastes }\end{array}$ & $\begin{array}{l}\text { former coking } \\
\text { plant site }\end{array}$ & $\begin{array}{l}\text { settling pond } \\
\text { site filled with } \\
\text { steel sludge }\end{array}$ & $\begin{array}{l}\text { former coking } \\
\text { plant site }\end{array}$ & $\begin{array}{l}\text { biopile-treated } \\
\text { PAH- } \\
\text { contaminated } \\
\text { soil mixed with } \\
\text { metal- } \\
\text { contaminated } \\
\text { sludge }\end{array}$ \\
\hline Year of construction & 2007 & 2011 & & & & 2013 \\
\hline Year of abandonment & & & 1980 & 1981 & 1975 & \\
\hline Age & 8 & 4 & 35 & 34 & 40 & 2 \\
\hline Localization & $\begin{array}{c}E: 918202 \\
\mathrm{~N}: 6905686\end{array}$ & $\begin{array}{c}E: 942352 \\
\mathrm{~N}: 6897630\end{array}$ & $\begin{array}{c}\text { E:918487 } \\
\text { N:6905891 }\end{array}$ & $\begin{array}{c}E: 920222 \\
\mathrm{~N}: 6911528\end{array}$ & $\begin{array}{c}E: 942262 \\
\mathrm{~N}: 6897475\end{array}$ & $\begin{array}{c}\text { E:938477 } \\
\mathrm{N}: 6864617\end{array}$ \\
\hline Texture & Silt loam & Silty clay loam & Loamy sand & Sandy loamy & Loam & Silt loam \\
\hline Clay & 11 & 40 & 6 & 4 & 27 & 15 \\
\hline WHC & $95 \pm 7$ & $59 \pm 8$ & $63 \pm 5$ & $58 \pm 4$ & $70 \pm 1$ & $64 \pm 1$ \\
\hline CEC & $22.0 \pm 2.9$ & $17.2 \pm 3.3$ & $17.2 \pm 1.8$ & $11.3 \pm 0.7$ & $15.5 \pm 1.4$ & $10.1 \pm 0.4$ \\
\hline $\mathrm{pH}$ & $7.9 \pm 0.2$ & $7.9 \pm 0.1$ & $7.9 \pm 0.1$ & $8.4 \pm 0.2$ & $7.2 \pm 0.2$ & $8.3 \pm 0.4$ \\
\hline Olsen Phosphorous & $62 \pm 5$ & $25 \pm 17$ & $39 \pm 16$ & $44 \pm 10$ & $36 \pm 2$ & $44 \pm 10$ \\
\hline $\mathrm{C}: \mathrm{N}$ & $30 \pm 6$ & $28 \pm 6$ & $26 \pm 5$ & $65 \pm 20$ & $20 \pm 3$ & $37 \pm 16$ \\
\hline $\mathrm{OM}$ & $39.7 \pm 5.9$ & $3.2 \pm 1.4$ & $16.7 \pm 6.3$ & $13.3 \pm 2.8$ & $4.8 \pm 3.0$ & $2.8 \pm 0.8$ \\
\hline $\mathrm{Ca}_{\text {exchangeable }}$ & $292 \pm 44$ & $713 \pm 144$ & $903 \pm 405$ & $2031 \pm 240$ & $786 \pm 84$ & $1123 \pm 130$ \\
\hline $\mathrm{K}_{\text {exchangeable }}$ & $706 \pm 105$ & $491 \pm 24$ & $155 \pm 36$ & $377 \pm 30$ & $131 \pm 50$ & $218 \pm 36$ \\
\hline $\mathrm{Mg}_{\text {exchangeable }}$ & $84 \pm 14$ & $152 \pm 38$ & $103 \pm 6$ & $312 \pm 47$ & $47 \pm 15$ & $72 \pm 34$ \\
\hline $\mathrm{Na}_{\text {exchangeable }}$ & $37 \pm 19$ & $34 \pm 28$ & $11 \pm 3$ & $42 \pm 11$ & $14 \pm 14$ & $55 \pm 29$ \\
\hline $\mathrm{Cd}_{\text {available }}$ & $0.22 \pm 0.05$ & $0.03 \pm 0.01$ & $0.16 \pm 0.05$ & $0.15 \pm 0.01$ & $0.10 \pm 0.03$ & $9.07 \pm 1.5$ \\
\hline $\mathrm{Pb}_{\text {available }}$ & $13 \pm 3$ & $14 \pm 10$ & $46 \pm 14$ & $18 \pm 5$ & $14 \pm 6$ & $110 \pm 60$ \\
\hline $\mathrm{Zn}_{\text {available }}$ & $29 \pm 9$ & $8 \pm 6$ & $45 \pm 20$ & $25 \pm 6$ & $7 \pm 2$ & $308 \pm 189$ \\
\hline $\mathrm{Cd}_{\text {total }}$ & $1.1 \pm 0.5$ & $0.1 \pm 0.2$ & $0.1 \pm 0.7$ & $1.4 \pm 0.1$ & $0.1 \pm 0.1$ & $23.6 \pm 6.9$ \\
\hline $\mathrm{Pb}_{\text {total }}$ & $150 \pm 53$ & $41 \pm 26$ & $346 \pm 106$ & $339 \pm 50$ & $37 \pm 10$ & $460 \pm 73$ \\
\hline $\mathrm{Zn}_{\text {total }}$ & $345 \pm 37$ & $131 \pm 2$ & $1162 \pm 396$ & $1196 \pm 122$ & $116 \pm 23$ & $1813 \pm 302$ \\
\hline$\Sigma 16$ PAH (US-EPA) & $170 \pm 49$ & $12 \pm 12$ & $179 \pm 136$ & $97 \pm 54$ & $142 \pm 90$ & $10 \pm 4$ \\
\hline
\end{tabular}


9 soils. Codes are used in Figures 1 to 4.

\begin{tabular}{|c|c|c|c|c|}
\hline & $\begin{array}{l}\text { Trait/Ecological } \\
\text { preference }\end{array}$ & $\begin{array}{l}\text { Code of } \\
\text { Trait/Ecological } \\
\text { preference } \\
\end{array}$ & Attribute & $\begin{array}{l}\text { Code of } \\
\text { attribute }\end{array}$ \\
\hline \multirow{10}{*}{$\begin{array}{l}\frac{\pi}{0} \\
\frac{0}{0} \\
\frac{0}{0} \\
0\end{array}$} & Body length & BLN & $\begin{array}{l}<1 \mathrm{~mm} \\
{[1: 2] \mathrm{mm}} \\
{[2: 3] \mathrm{mm}} \\
>3 \mathrm{~mm} \\
\end{array}$ & $\begin{array}{l}-<1 \\
-1 \_2 \\
-2 \_3 \\
->3\end{array}$ \\
\hline & Body shape & BSH & $\begin{array}{l}\text { Spherical } \\
\text { Cylindrical } \\
\end{array}$ & $\begin{array}{l}\text { _sph } \\
\text { cyl }\end{array}$ \\
\hline & Ocelli (visual organ) & OCE & $\begin{array}{l}\text { No ocellus } \\
1 \text { or } 2 \text { pair of ocelli } \\
3 \text { or } 4 \text { pair of ocelli } \\
5,6,7 \text { or } 8 \text { pair of ocelli }\end{array}$ & $\begin{array}{l}-0 \\
-1 \_2 \\
-3 \_4 \\
-5 \_8 \\
\end{array}$ \\
\hline & Post Antennal Organ* & PAO & $\begin{array}{l}\text { PAO present } \\
\text { PAO absent }\end{array}$ & $\begin{array}{l}\text { _present } \\
\text { _absent }\end{array}$ \\
\hline & Pigmentation & PIG & $\begin{array}{l}\text { Pigmented } \\
\text { Non-pigmented } \\
\end{array}$ & $\begin{array}{l}\text { _present } \\
\text { absent }\end{array}$ \\
\hline & Motion strategy & MS & $\begin{array}{l}\text { Furca present } \\
\text { Furca absent } \\
\end{array}$ & $\begin{array}{l}\text { furca } \\
\text { no.furca }\end{array}$ \\
\hline & Reproduction & REP & $\begin{array}{l}\text { Sexual reproduction type } \\
\text { Asexual reproduction type }\end{array}$ & $\begin{array}{l}\text { _sex } \\
\text { asex }\end{array}$ \\
\hline & Vertical distribution & DIST & $\begin{array}{l}\text { Epigenic } \\
\text { Hemiedaphic } \\
\text { Euedaphic }\end{array}$ & $\begin{array}{l}\text { _epi } \\
\text { _hemi } \\
\text { _eu }\end{array}$ \\
\hline & $\begin{array}{l}\text { Micro-habitat } \\
\text { preference }\end{array}$ & MHABI & $\begin{array}{l}\text { Inhabiting in decaying micro-habitat } \\
\text { Inhabiting in mineral micro-habitat } \\
\text { Inhabiting in root micro-habitat } \\
\text { Inhabiting in soil micro-habitat } \\
\text { Inhabiting in vegetal micro-habitat } \\
\text { Inhabiting in wet micro-habitat }\end{array}$ & $\begin{array}{l}\text { _dec } \\
\text { _min } \\
\text { _root } \\
\text { _soil } \\
\text { _veg } \\
\text { _wet }\end{array}$ \\
\hline & Habitat preference & HABI & $\begin{array}{l}\text { Inhabiting in forest and grassland } \\
\text { Inhabiting in agricultural area } \\
\text { Inhabiting in artificial area } \\
\text { Inhabiting in wetland }\end{array}$ & $\begin{array}{l}\text { _forest_grassland } \\
\text { _agri } \\
\text { _arti } \\
\text { _wet }\end{array}$ \\
\hline \multirow{6}{*}{ 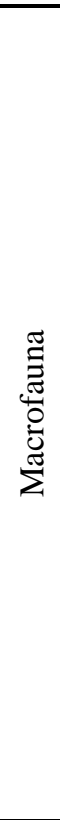 } & Body length & BLN & $\begin{array}{l}<2.5 \mathrm{~mm} \\
{[2.5: 5] \mathrm{mm}} \\
{[5: 10] \mathrm{mm}} \\
{[10: 20] \mathrm{mm}} \\
>20 \mathrm{~mm} \\
\end{array}$ & $\begin{array}{l}-<2.5 \\
-2.5 \_5 \\
-5 \_10 \\
-10 \_20 \\
+>20 \\
\end{array}$ \\
\hline & Integument & INT & $\begin{array}{l}\text { Sclerotized } \\
\text { Non-sclerotized } \\
\end{array}$ & $\begin{array}{l}\text { _scl } \\
\text { nno.scl }\end{array}$ \\
\hline & Mouth-part type & MthT & $\begin{array}{l}\text { Absent } \\
\text { Piercing-sucking } \\
\text { Swallowing } \\
\text { Sucking } \\
\text { Chewing } \\
\end{array}$ & $\begin{array}{l}\text { _absent } \\
\text { _piercing.sucking } \\
\text { _swallowing } \\
\text { _sucking } \\
\text { _chewing } \\
\end{array}$ \\
\hline & Diet & DIET & $\begin{array}{l}\text { Zoophagous } \\
\text { Phytophagous } \\
\text { Geophagous } \\
\text { Detritivore } \\
\end{array}$ & $\begin{array}{l}\text { zoo } \\
\text { _phyto } \\
\text { _geo } \\
\text { _detri }\end{array}$ \\
\hline & $\begin{array}{l}\text { Micro-habitat } \\
\text { preference }\end{array}$ & MHABI & $\begin{array}{l}\text { Inhabiting in decaying micro-habitat } \\
\text { Inhabiting in mineral micro-habitat } \\
\text { Inhabiting in vegetal micro-habitat }\end{array}$ & $\begin{array}{l}\text { _dec } \\
\text { _min } \\
\text { _veg }\end{array}$ \\
\hline & Habitat preference & HABI & $\begin{array}{l}\text { Inhabiting in forest and grassland } \\
\text { Inhabiting in agricultural habitat } \\
\text { Inhabiting in artificial habitat } \\
\text { Inhabiting in wetland }\end{array}$ & $\begin{array}{l}\text { _forest_grassland } \\
\text { _agri } \\
\text { _arti } \\
\text { _wet }\end{array}$ \\
\hline
\end{tabular}

\footnotetext{
* The Post Antennal Organ (PAO) is an organ composed of thermo-, hygro-, or chemo-sensitive receptors.
} 
12 Table 3: Taxonomic and functional indices for Collembola communities in the six derelict soils and

13 for macrofauna communities in 5 derelict soils. Means \pm SD $(n=5$, except for CCS where $n=4)$.

14 Different letters indicate significant differences among soils $(\mathrm{P}<0.05$; Kruskal-Wallis test followed by multiple comparisons of rank distribution with Fisher's LSD test). TRic=Taxonomic richness;

16 TEve=Taxonomic evenness; FRic=Functional richness; FEve=Functional evenness. CS=constructed

17 soil; $\mathrm{WL}=$ waste landfill soil; $\mathrm{CP} 1=$ coking plant soil $1 ; \mathrm{SP}=$ settling pond soil; $\mathrm{CP} 2=$ coking plant soil 2;

$18 \mathrm{CCS}=$ constructed and contaminated soil.

19

\begin{tabular}{|c|c|c|c|c|c|c|c|}
\hline & & \multicolumn{6}{|c|}{ Soils } \\
\hline & & CS & $\mathbf{W L}$ & CP1 & SP & CP2 & $\mathrm{CCS}$ \\
\hline & & \multicolumn{6}{|c|}{ Indices for Collembola community } \\
\hline \multirow{2}{*}{ Taxonomic } & TRic & $3.4 \pm 1.3 \mathbf{b}$ & $4.2 \pm 0.8 \mathbf{a b}$ & $6 \pm 1.4 \mathbf{a b}$ & $7 \pm 0.8 \mathbf{a}$ & $7 \pm 2.2 \mathbf{a}$ & $5.8 \pm 1 \mathbf{a}$ \\
\hline & TEve & $0.67 \pm 0.23$ & $0.63 \pm 0.18$ & $0.46 \pm 0.12$ & $0.52 \pm 0.1$ & $0.52 \pm 0.12$ & $0.74 \pm 0.12$ \\
\hline \multirow{3}{*}{ Functional } & FRic & $0.07 \pm 0.04 \mathbf{a b}$ & $0.04 \pm 0.03 \mathbf{b}$ & $0.13 \pm 0.04 \mathbf{a}$ & $0.14 \pm 0.03 \mathbf{a}$ & $0.16 \pm 0.04 \mathbf{a}$ & $0.02 \pm 0.01 \mathbf{b}$ \\
\hline & FEve & $0.62 \pm 0.10$ & $0.56 \pm 0.22$ & $0.68 \pm 0.15$ & $0.65 \pm 0.08$ & $0.71 \pm 0.04$ & $0.68 \pm 0.15$ \\
\hline & & \multicolumn{6}{|c|}{ Indices for macrofauna community } \\
\hline \multirow{2}{*}{ Taxonomic } & TRich & $16.2 \pm 4.4 \mathbf{a}$ & $13.8 \pm 4.9 \mathbf{a}$ & $8.7 \pm 3.1 \mathbf{a b}$ & $6.6 \pm 3.2 \mathbf{b}$ & $6.0 \pm 3.8 \mathbf{b}$ & $N A$ \\
\hline & TEve & $0.53 \pm 0.06$ & $0.62 \pm 0.11$ & $0.65 \pm 0.27$ & $0.71 \pm 0.14$ & $0.71 \pm 0.23$ & $N A$ \\
\hline \multirow{2}{*}{ Functional } & FRich & $0.14 \pm 0.01 \mathbf{a}$ & $0.10 \pm 0.05 \mathbf{a b}$ & $0.06 \pm 0.05 \mathbf{b}$ & $0.07 \pm 0.05 \mathbf{b}$ & $0.07 \pm 0.05 \mathbf{b}$ & $N A$ \\
\hline & FEve & $0.76 \pm 0.03$ & $0.76 \pm 0.07$ & $0.78 \pm 0.12$ & $0.77 \pm 0.10$ & $0.74 \pm 0.14$ & $N A$ \\
\hline
\end{tabular}

20 


\section{FIGURE CAPTIONS:}

2 Figure 1: Community Weighted Mean (CWM) values of Collembola communities sampled in each

3 derelict soil, calculated for the following traits: number of ocelli, body length, vertical distribution,

4 presence of furca, body shape, presence of PAO, pigmentation, reproduction type, habitat preference,

5 and micro-habitat preference. Means $(n=5$, except for CCS where $n=4)$. Different letters indicate

6 significant differences among the 6 soils $(\mathrm{P}<0.05)$ using Kruskal-Wallis tests followed by the Dunn's

7 test of multiple comparisons with Bonferroni adjustment. CS=constructed soil; WL=waste landfill

8 soil; $\mathrm{CP} 1=$ coking plant soil 1 ; $\mathrm{SP}=$ settling pond soil; $\mathrm{CP} 2=$ coking plant soil 2 ; $\mathrm{CCS}=$ constructed and

9 contaminated soil.

Figure 2: Projection of the coordinates of each soil replicate on the first two main components RLQ1 and RLQ2 (A), mapping of Collembola species density coordinates (B), and plot of attributes of each trait linked to abiotic soil parameters $(\mathrm{C}) . \mathrm{PAH}=$ sum of the $16 \mathrm{PAH}$ concentrations; Clay=proportion of clay; $\mathrm{P}=$ available phosphorous (Olsen method); $\mathrm{OM}=$ Organic Matter; WHC=Water Holding Capacity; $\mathrm{CEC}=$ Cation Exchange Capacity; $\mathrm{C}: \mathrm{N}=$ carbon/nitrogen ratio; [Exchangeable cations by cobaltihexamine extraction] $\mathrm{Ca}=$ calcium; $\mathrm{Na}=$ sodium; $\mathrm{K}=$ potassium; $\mathrm{Mg}=$ magnesium. [Available elements] $\mathrm{Pb}=\mathrm{lead} ; \mathrm{Zn}=\mathrm{zinc} ; \mathrm{Cd}=$ cadmium; $\mathrm{Age}=$ time since the last anthropogenic action. $\mathrm{CS}=$ constructed soil; $\mathrm{WL}=$ waste landfill soil; $\mathrm{CP} 1=$ coking plant 1 soil; $\mathrm{SP}=$ settling pond soil; CP2=coking plant 2 soil; $\mathrm{CCS}=$ constructed and contaminated soil. See Table 2 for the codes of traits/ecological preferences and see Supplementary materials, Appendix A for Collembola species codes.

Figure 3: Community Weighted Mean (CWM) values of macrofauna communities sampled in each derelict soil, calculated for the following traits: body length, diet type, integument type, mouth-part type, habitat preference, and micro-habitat preference. Means $(n=5)$. Different letters indicate 
significant differences among the 5 soils $(\mathrm{P}<0.05)$ using Kruskal-Wallis tests followed by the Dunn's test of multiple comparisons with Bonferroni adjustment. $\mathrm{CS}=$ constructed soil; WL=waste landfill soil; $\mathrm{CP} 1=$ coking plant 1 soil; $\mathrm{SP}=$ settling pond soil; $\mathrm{CP} 2=$ coking plant 2 soil.

Figure 4: Projection of the coordinates of each soil replicate on the first two main components RLQ1 and RLQ2 (A), mapping of macrofauna taxon density coordinates (B), and plot of attributes of each trait linked to abiotic soil parameters $(\mathrm{C}) . \mathrm{PAH}=$ sum of the $16 \mathrm{PAH}$ concentrations; Clay=proportion of clay; $\mathrm{P}=$ available phosphorous (Olsen method); $\mathrm{OM}=$ Organic Matter; WHC=Water Holding Capacity; $\mathrm{CEC}=$ Cation Exchange Capacity; $\mathrm{C}: \mathrm{N}=$ carbon/nitrogen ratio; [Exchangeable cations by cobaltihexamine extraction] $\mathrm{Ca}=$ calcium; $\mathrm{Na}=$ sodium; $\mathrm{K}=$ potassium; $\mathrm{Mg}=$ magnesium. [Available elements] $\mathrm{Pb}=\mathrm{lead} ; \mathrm{Zn}=\mathrm{zinc} ; \mathrm{Cd}=\mathrm{cadmium} ; \mathrm{Age}=$ time since the last anthropogenic action. $\mathrm{CS}=$ constructed soil; $\mathrm{WL}=$ waste landfill soil; $\mathrm{CP} 1=$ coking plant 1 soil; $\mathrm{SP}=$ settling pond soil; $\mathrm{CP} 2=$ coking plant 2 soil. See Table 2 for the codes of traits/ecological preferences and see Supplementary materials, Appendix B for macrofauna taxon codes. 


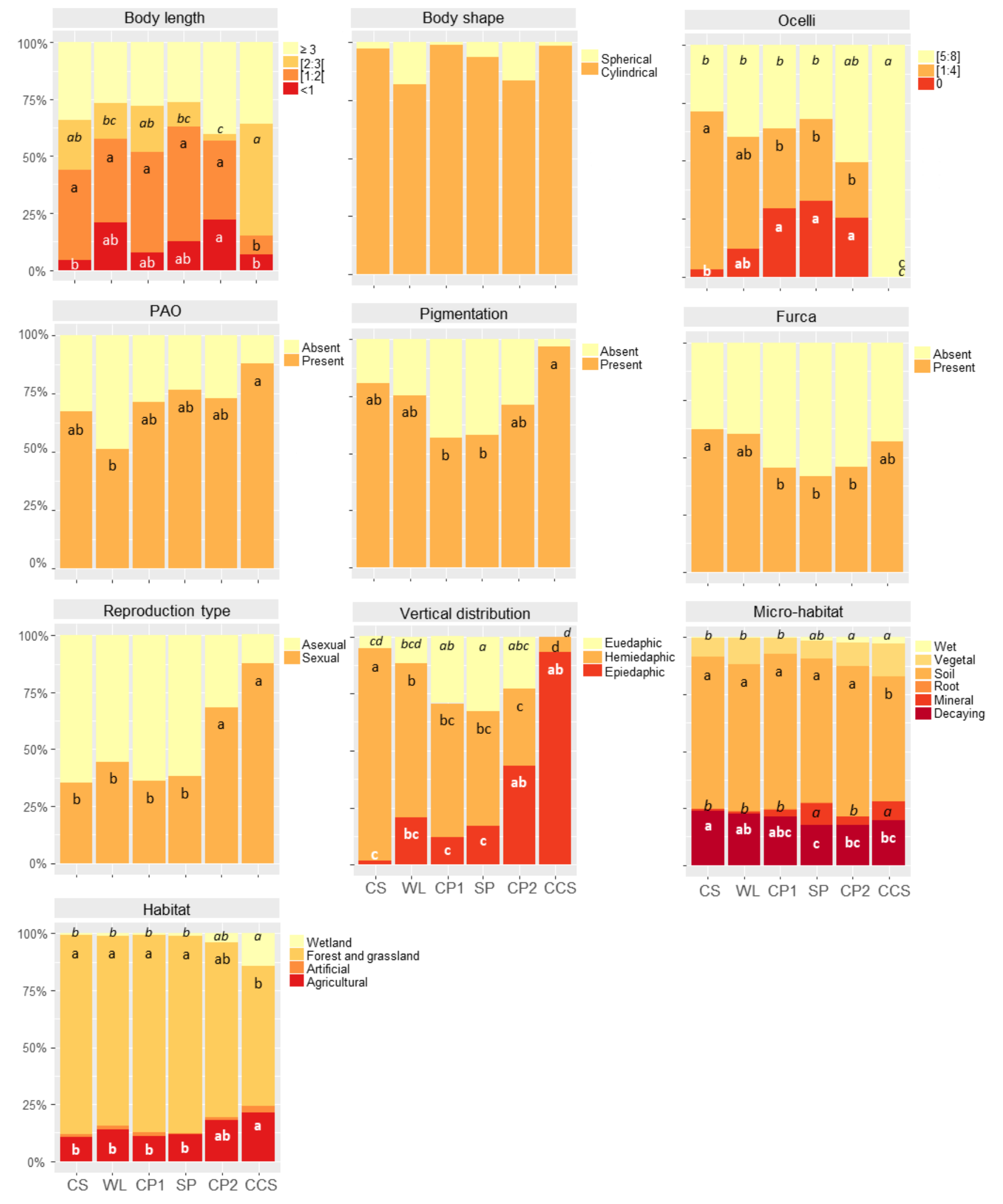

Figure 1 

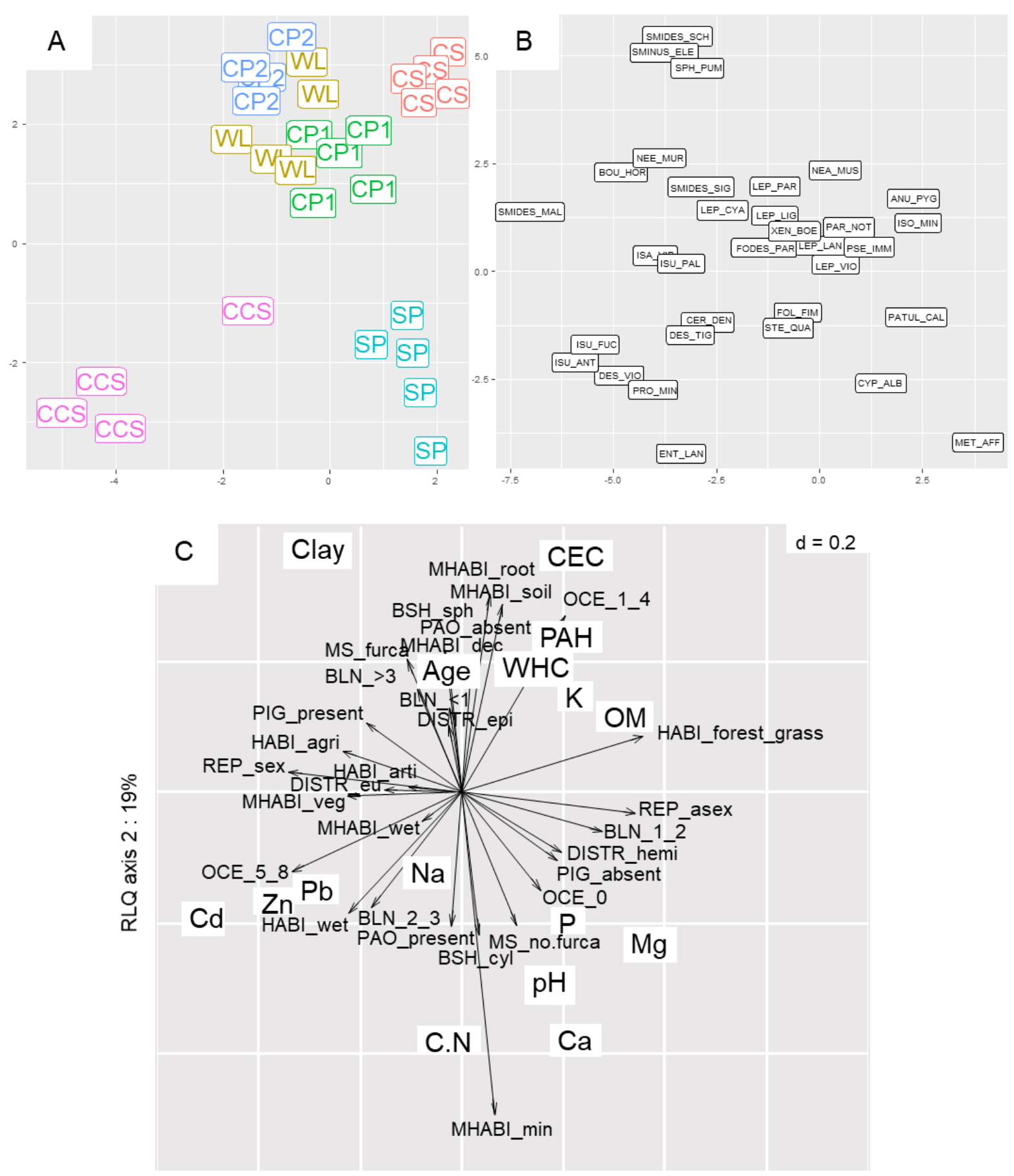

RLQ axis $1: 69 \%$

Figure 2 


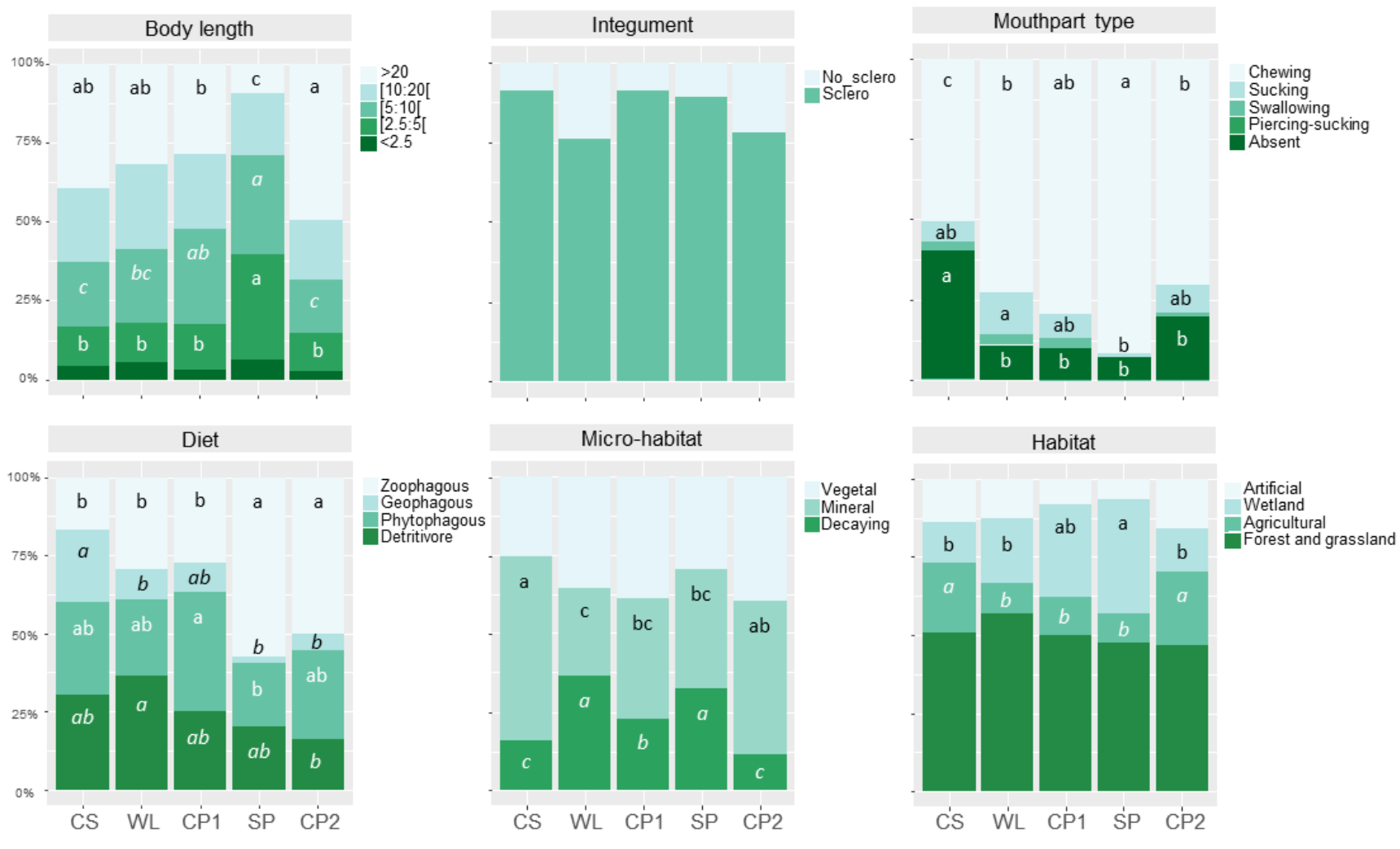

50

Figure 3

51 

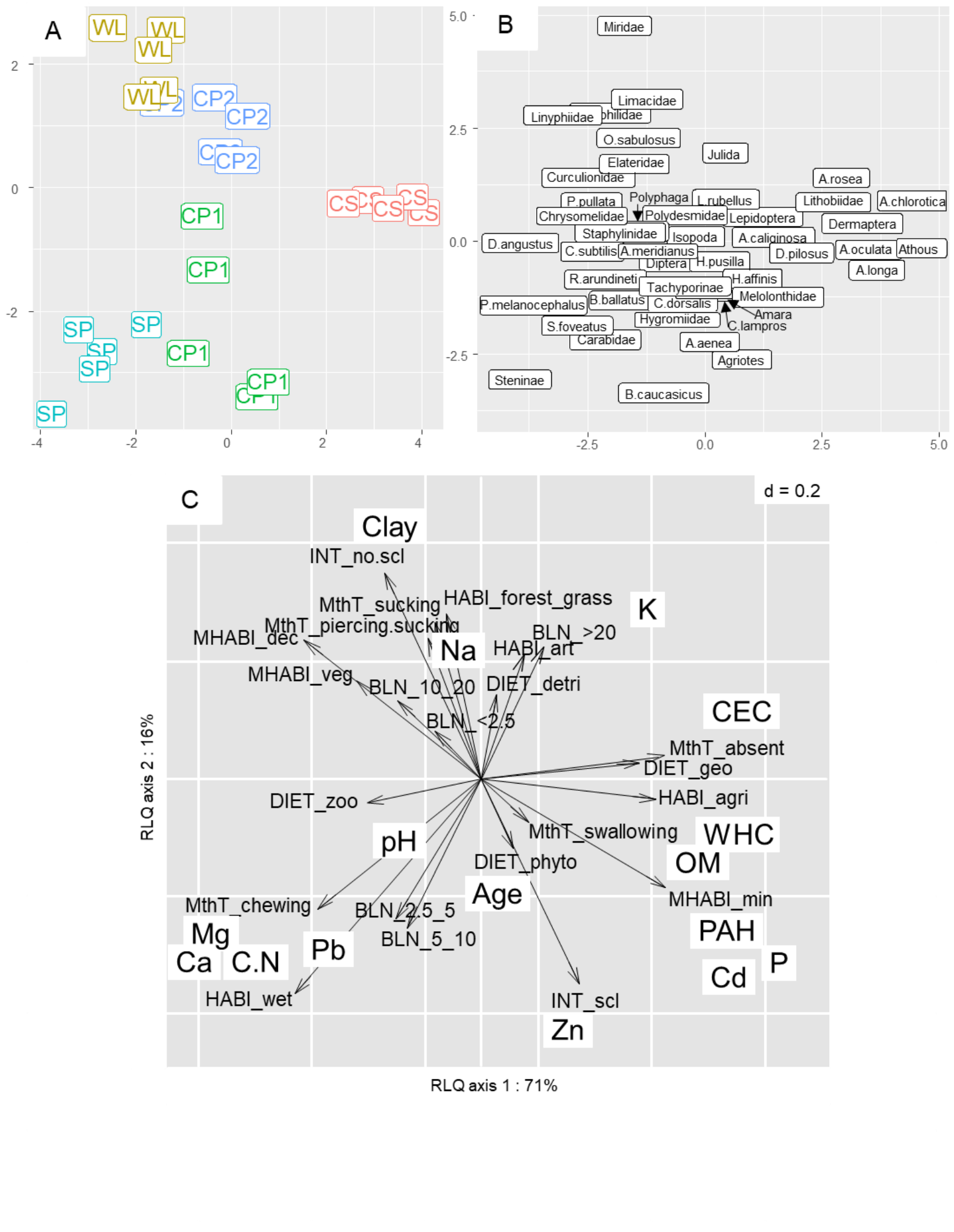

Figure 4 